\title{
1 Trajectories of imitation skills in 2 preschoolers with Autism Spectrum 3 Disorders
}

1. Autism Brain and Behavior (ABB) Lab, Department of Psychiatry, Faculty of Medicine, University of Geneva, Geneva, Switzerland; Irene.Pittet@unige.ch (I.P.); Nada.Kojovic@unige.ch (N.K.); Marie.Schaer@unige.ch (M.S.);

9 2. Fondation Pôle Autisme, Geneva, Switzerland; martina.franchini@pole-autisme.ch (M.F.)

\section{Abstract}

Imitation skills play a crucial role in social cognitive development from early childhood. Many studies have shown a deficit in imitation skills in children with Autism Spectrum Disorders (ASD). Little is known about the development of imitation behaviors in children with ASD. This study aims to measure the trajectories of early imitation skills in preschoolers with ASD and how these skills impact other areas of early development. For this purpose, we assessed imitation, language and cognition skills in 177 children with ASD and 43 typically developing children (TD) aged 2 to 5 years old, 126 of which were followed longitudinally, yielding a total of 396 time-points. Our results confirmed the presence of an early imitation deficit in toddlers with ASD compared to TD children. The study of the trajectories showed that these difficulties were marked at the age of two years, and gradually decreased until the age of 5 years old. Imitation skills were strongly linked with cognitive, language skills and level of symptoms in our ASD group at baseline. Moreover, the imitation skills at baseline were predictive of the language gains a year later in our ASD group. Using a data-driven clustering method, we delineated different developmental trajectories of imitation skills within the ASD group. The clinical implications of the findings are discussed, particularly the impact of an early imitation deficit on other areas of competence of the young child.

\section{Background}

Imitation skills play a crucial role in early development and are considered an essential component of social and cognitive development during the first years of life. Indeed, newborns begin to imitate tongue profusion and mouth opening after only a few hours of life (Heimann \& Tjus, 2019; Meltzoff \& Moore, 1989). Later, infants begin to imitate vocalisations, actions on objects and gestures. During the two first years of life, children gradually increase 
medRxiv preprint doi: https://doi.org/10.1101/2021.03.24.21254258; this version posted March 26, 2021. The copyright holder for this preprint (which was not certified by peer review) is the author/funder, who has granted medRxiv a license to display the preprint in It is made available under a CC-BY-NC-ND 4.0 International license .

34

their cognitive and social abilities (Vivanti \& Hamilton, 2014). Children imitate their siblings, peers and parents at every moment to learn new abilities (Howe et al., 2018; Zmyj \& Seehagen, 2013). Imitation is an essential lever for learning of new motor skills (Pfeifer et al., 2008), and cognitive skills (Hurley \& Chater, 2005; Strid et al., 2006; Vivanti et al., 2013). Besides the role in learning, imitation has an important social function (Uzgiris, 1981, as cited in Ingersoll, 2008). From the earliest moments, caregivers and infants engage in reciprocal imitation during face-to-face interactions. Through this choreography of imitating each other's vocalisations and facial expressions they will share social interest, affective states, take turns and build a fundament for the development of complex social skills. Indeed, the literature has amply demonstrated that imitation plays a vital role in the development of social communication (Hanika \& Boyer, 2019; Toth et al., 2006).

The disruption in early imitation skills can have a tremendous repercussion on various developmental aspects, especially socio-communicative development that is altered in autism. Autism Spectrum Disorder (ASD) is a neurodevelopmental disorder characterized by impairments in social communication, interaction and restricted patterns of interests and activities (American Psychiatric Association, 2013). Indeed, a large body of literature has highlighted broad imitation deficits in children with ASD (Girardot et al., 2009; McDuffie et al., 2007; Plavnick \& Hume, 2014; Rogers et al., 1996; Thurm et al., 2007; Vivanti \& Hamilton, 2014; Zwaigenbaum et al., 2005) using various imitation measures (Vivanti \& Hamilton, 2014). Early imitation deficits were linked to difficulties in social communication skills, such as language (Ingersoll \& Meyer, 2011; Poon et al., 2012), joint attention (Villalobos et al., 2005) and social interaction difficulties (Ingersoll, 2008). In addition, such a deficit could hinder the effectiveness of intervention methods for children with ASD, as many of them rely upon imitation to teach new abilities (Dawson et al., 2010; Delano, 2007; Espanola Aguirre \& Gutierrez, 2019). Given the critical role that the imitation skills play in typical development, precise characterization of the deficit in this domain in ASD is of utmost importance.

Even though imitation difficulties in ASD are relatively well documented, the developmental trajectories of imitation have received less attention to date in this population. Prospective studies following infants at risk of developing ASD report difficulties in imitation skills in children later diagnosed with ASD from 12 months of age. For example, Young and colleagues (2011) conducted a longitudinal study with 248 children between 12 and 24 months of age and found a delayed imitation development in children who developed ASD by age 3 years compared to the TD group. Likewise, Poon and colleagues (2012) found that infants of 9-12 months of age who are later diagnosed with ASD show a considerable delay in imitation skills. These results have led some research groups to explore if imitation could be used for screening ASD in high-risk siblings. Rowberry and colleagues (2015), for instance, found that poor imitation reported by parents in the First Year Inventory (FYI) (Baranek, Watson, Crais, \& Reznick, 2003) can be an early marker of ASD in 12-months-old high-risk siblings. The results of the various studies cited above highlight this imitative deficit in young children with ASD 
medRxiv preprint doi: https://doi.org/10.1101/2021.03.24.21254258; this version posted March 26, 2021. The copyright holder for this preprint (which was not certified by peer review) is the author/funder, who has granted medRxiv a license to display the preprint in It is made available under a CC-BY-NC-ND 4.0 International license .

75

and the importance of increasing and detailing knowledge about the development of this crucial skill and the consequences of such difficulties.

The present study aims to compare the developmental trajectories of imitative skills between preschoolers with ASD and a group of matched TD children, using a total of 396 longitudinal assessments collected between the age of 2 and 5 years old. Based on previous literature (Girardot et al., 2009; McDuffie et al., 2007; Plavnick \& Hume, 2014; Rogers et al., 1996; Thurm et al., 2007; Vivanti \& Hamilton, 2014; Zwaigenbaum et al., 2005), we expected a delayed development of imitation skills in children with ASD in comparison to TD children. Second, we investigated how imitation skills related to the level of symptoms, cognitive and communication skills in the ASD group at baseline and after one year to explore the consequences of this deficit on the different development areas. We hypothesized that a deficit in imitation skills is linked with severity of symptoms and difficulties in developmental domains at the baseline and one year after (Ingersoll \& Meyer, 2011; Poon et al., 2012). Finally, we explored the extent to which there could be different imitation trajectories inside the ASD group, as this population is characterized by a great heterogeneity of profiles and manifestations (Wiggins et al., 2012).

\section{Material \& methods}

\section{Participants}

The participants in this study were recruited as part of the Geneva Autism Cohort (Franchini \& al., 2016, 2017, 2018; Kojovic \& al., 2019; Robain \& al., 2020; Sperdin \& al., 2018). The University's Institutional Review Board approved this study. All families provided written informed consent to participate. For the current study, a total of 220 participants were included, 177 with ASD and 43 typically developing children (TD) (see Table 1 and Table S1 in Supplementary Materials). Among these, 126 were followed longitudinally, yielding a total of 396 time-points (78 subjects had 2, 46 had 3, and 2 participants had 4 time-points), each timepoint was separated by 12 months, except for two children for whom the two time-points are separated by 24 months (see Figure 1). The inclusion criteria for ASD group was a clinical diagnosis of autism according to the DSM- 5 criteria (American Psychiatric Association, 2013). The clinical diagnosis was confirmed by the scores exceeding the cut-off for autism at the ADOS-G (Lord et al., 2000) or ADOS-2 (Lord \& al., 2012) (see Measures for more details). Children from the TD group had no developmental concerns, no first or second-degree family member diagnosed with autism, and were all administered the ADOS diagnostic test to exclude the presence of ASD symptoms (see Table 1). Participants were aged between 2.0 and 5.0 years, and the two groups did not differ by age $(U=351, p=0.429)$ nor sex $(p=0.156)$. 
medRxiv preprint doi: https://doi.org/10.1101/2021.03.24.21254258; this version posted March 26, 2021. The copyright holder for this preprint (which was not certified by peer review) is the author/funder, who has granted medRxiv a license to display the preprint in It is made available under a CC-BY-NC-ND 4.0 International license.

112 Table 1. Statistical Comparison Between Children With ASD and Children with TD at Baseline in 113 Terms of Demographic, Clinical, Cognitive Features

114

\begin{tabular}{|c|c|c|c|}
\hline & ASD - Mean $(S D) n=177$ & $\mathrm{TD}-\operatorname{Mean}(S D) n=43$ & $p$-value* \\
\hline Sex & 24 ○ / 153 O’ & 10 \% / 33 o & $0.156^{1}$ \\
\hline Age (years old) & $3.09(0.8)$ & $2.93(0.7)$ & $0.429^{2}$ \\
\hline ADOS Total symptom severity & $7.7(1.8)$ & $1.02(1.2)$ & $<0.001^{2}$ \\
\hline
\end{tabular}

PEP-3

\begin{tabular}{cccc} 
VPC (raw score) & $28.47(\mathbf{1 5})$ & $\mathbf{4 5}(\mathbf{9 . 4 )}$ & $<0.00 \mathbf{1}^{2}$ \\
EL (raw score) & $9.22(\mathbf{1 0 . 2})$ & $\mathbf{2 5 . 7 7 ( 8 . 8 )}$ & $<0.00 \mathbf{1}^{2}$ \\
RL (raw score) & $\mathbf{1 3 . 4 1 ( 1 0 . 8 )}$ & $30.57(5.2)$ & $<0.001^{2}$ \\
\hline $\begin{array}{l}\text { VABS-II Adaptive Behavior } \\
\text { Composite }\end{array}$ & $77.61(11.5)$ & $\mathbf{1 0 2 . 9 ( 8 . 5 )}$ & $<0.001^{2}$ \\
\hline
\end{tabular}

115

116

117

118

119

120

121

Note. ADOS = Autism Diagnosis Observation Schedule $;$ PEP-3 = PsychoEducational Profile, 3rd edition ; VPC = Verbal and Preverbal Cognition ; EL = Expressive language ; RL = Receptive language ; VABS-II = Vineland Adaptive Behavior Scales, 2nd edition.

* $\mathrm{p}$ value of Fisher's exact test ${ }^{1}$ and Mann-Whitney tests ${ }^{2}$ of differences between the ASD and TD groups. Significant results are shown in bold. 
medRxiv preprint doi: https://doi.org/10.1101/2021.03.24.21254258; this version posted March 26, 2021. The copyright holder for this preprint (which was not certified by peer review) is the author/funder, who has granted medRxiv a license to display the preprint in It is made available under a CC-BY-NC-ND 4.0 International license

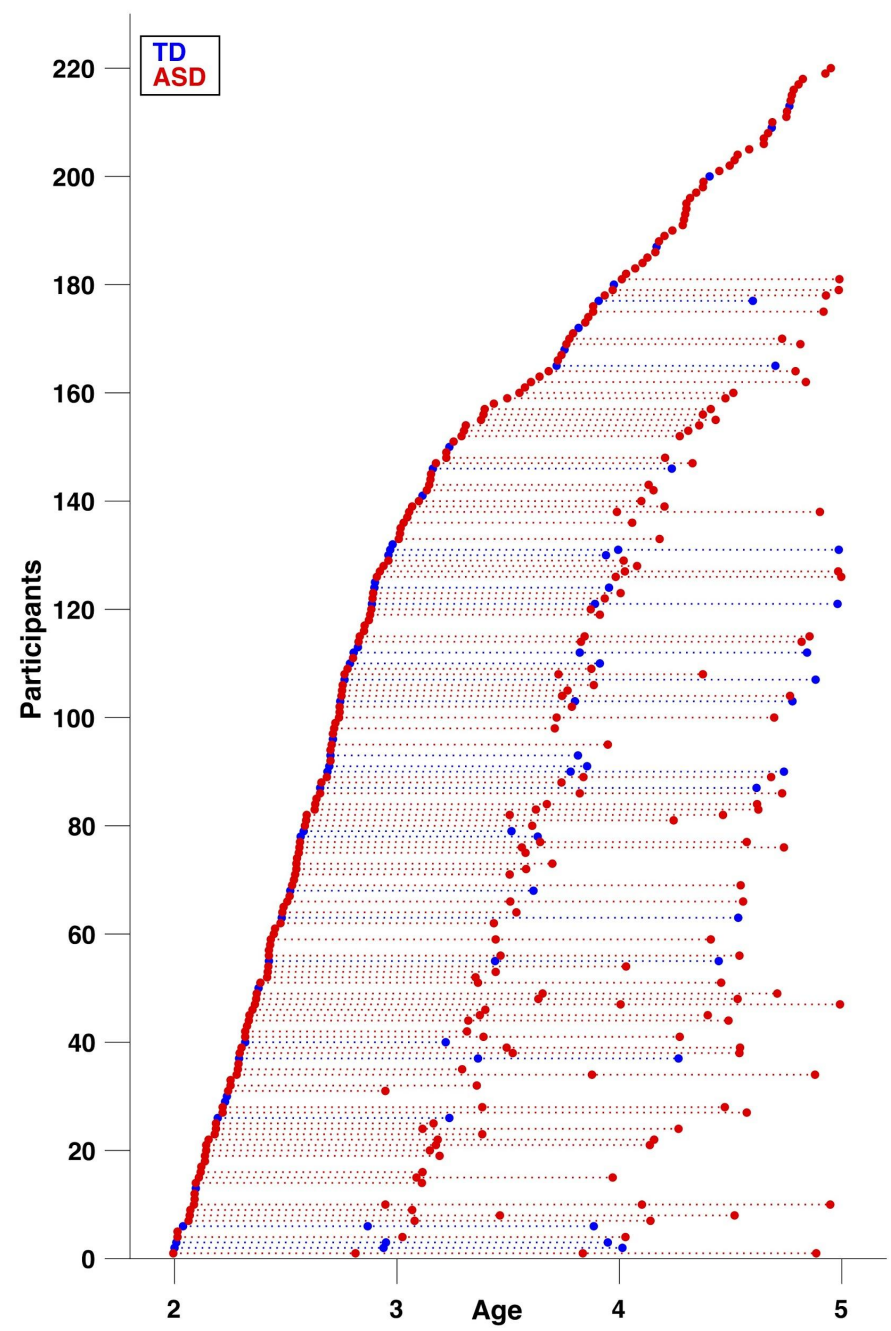

Figure 1. Data distribution available for each group from our longitudinal study. Circles (red = ASD, blue $=\mathrm{TD}$ ) denote visits/time-points, repeated visits of the same subject are connected with a dotted line.

\section{Measures}

\section{Imitation}

For the measure of imitation skills we used the Visuo-Motor Imitation scale of the PEP-3 (Schopler \& al., 2005) (for a detailed description of this test please refer to Supplementary Materials). This scale includes 10 items of imitation, assessed on a 3 point scale $(0=$ absence of imitation, 1 = equivoque, partial or prompted imitation, 2 = complete imitation of the skill). Raw scores range between 0 and 20, which allows enough variability to highlight the heterogeneity of imitation profiles.

The scale comprises the imitation of familiar actions and imitation with explicit instruction.

138 Vivanti \& Hamilton (2014) distinguished two types of imitation that we find in this scale : true imitation (copying both the mean and the goal of the action) and stimulus enhancement (perform 
medRxiv preprint doi: https://doi.org/10.1101/2021.03.24.21254258; this version posted March 26, 2021. The copyright holder for this preprint (which was not certified by peer review) is the author/funder, who has granted medRxiv a license to display the preprint in It is made available under a CC-BY-NC-ND 4.0 International license.

140

141

142

143

144

145

146

147

148

149

150

151

152

153

154

155

156

157

158

159

160

161

162

163

164

165

166

167

168

169

170

171

172

173

174

175

a specific action on a stimulus after having been made attentive to this stimulus by another person). For instance, one item of the PEP-3 is to organize a fake birthday party to explore imitation of daily actions like eating etc. (stimulus enhancement). For another one, the examiner touches her/his nose and says "Now it's your turn" (true imitation of meaningless actions).

\section{Level of symptoms of autism}

Each participant was assessed with the Autism Diagnosis Observation Schedule, 2nd edition (Lord et al., 2012) or Autism Diagnosis Observation Schedule, Generic (ADOS-G; Lord et al., 2000). For subjects who underwent the earlier ADOS version (ADOS-G) assessment, the scores were transformed according to the revised ADOS algorithm (Gotham et al., 2009) to ensure comparability with ADOS-2. The ADOS Calibrated Severity Score (ADOS-CCS; Gotham et al., 2009), a measure of symptom severity relatively independent of language levels and age, was then used for all subjects included in this study.

\section{Developmental functioning}

\section{Mullen Scale of Early Learning}

Developmental functioning of all children included in the present study was assessed with the Psychoeducational Profile, 3rd edition (Schopler et al., 2005). Nevertheless, as our aim was to test the relation between the imitation skills (VMI subscale of PEP-3) and the developmental functioning, we decided to use another measure than the PEP-3 to estimate the level of developmental functioning. We thus used the Mullen Scale of Early Learning-MSEL (Mullen, 1995), which was available for 133 out of the 177 children with ASD included in this study (this measure was indeed added at a later point in our cohort protocol and was thus missing for the data collected earlier).

The MSEL scale is developed for the assessment of typically developing children consists of 5 domains with items organized according to developmental stages and their level of difficulty : Gross Motor (GM), Visual Reception (VR), Fine Motor (FM), Receptive Language (RL) and Expressive Language (EL). This assessment yields a global composite score (Early Learning Composite ; ELC) by adding the four cognitive subscales (VR, FM, RL, EL), and has a mean of 100 and standard deviation of 15 . For the global developmental functioning in this study, we considered the standard composite score (ELC). For the measure of individual domains (Receptive and Expressive language), we used the measure of age equivalents (AE). We opted for the AE scores as the standard T scores of the MSEL subscales show poor sensitivity in the lower functioning end of the continuum (floor of 20), and an important number of our participants had this lowest score. 
medRxiv preprint doi: https://doi.org/10.1101/2021.03.24.21254258; this version posted March 26, 2021. The copyright holder for this preprint (which was not certified by peer review) is the author/funder, who has granted medRxiv a license to display the preprint in It is made available under a CC-BY-NC-ND 4.0 International license .

176

177

178

179

180

181

182

183

184

185

186

187

188

189

190

191

192

193

194

\section{Statistical Analyses}

Between-group analyses (ASD vs TD)

\section{Group comparison of imitation skills}

To compare imitation skills at baseline between children with ASD $(n=177)$ and TD children $(n=43)$, we conducted a $t$-test using the raw scores obtained from the Visuo-Motor Imitation scale of PEP-3 (Schopler \& al., 2005).

\section{Imitation trajectories over time}

To compare trajectories of imitation skills over time between ASD and TD children, we used mixed model regression analysis applied on raw imitation scores including all available time points (total of 396 time-points, $N=220, n_{A S D}=177, n_{T D}=43$ ). This model is particularly adapted for dealing with nested data, such as multiple time points, and has been applied in our previous studies involving a variable number of time points (Franchini \& al., 2018; Maeder \& al., 2016; Mancini \& al., 2019; Mutlu \& al., 2013; Schneider \& al., 2014). This analysis estimates developmental trajectories by fitting random-slope models to the data, taking into account both within-subject and between-subject effects. Different models (constant, linear, quadratic, or cubic) were fitted using the nlmefit function in MATLAB R2011b (MathWorks) for each variable. A Bayesian Information Criterion (BIC)-based model selection method was then employed.

\section{Within-group analyses (ASD group)}

\section{Relation of imitation to the symptom severity and developmental levels at baseline}

To explore how an imitation deficit is related to difficulties in other areas of development, we used the cross-sectional data obtained from the ASD group for whom the Mullen Scale of Early Learning was available ( $n=133,113$ males / 20 females, age range: $2.0-4.8$ years old). The association of imitation with the level of autistic symptoms (CSS ADOS), global cognitive functioning (the Early Learning Composite of MSEL) and more specifically, communication skills (age equivalents on Receptive and Expressive Language subscales of MSEL) was assessed using spearman's correlations. Results were considered significant at the level of $p<$ .0125 (after applying the Bonferroni correction for multiple comparisons).

\section{Imitation at baseline as a predictor of symptom severity and developmental levels}

We then explored the predictive power of the early imitative skills at baseline on the evolution of autistic symptoms and developmental domains in our ASD group one year after the initial measurement. More specifically, we tested how the imitation predicted the symptom change, 
medRxiv preprint doi: https://doi.org/10.1101/2021.03.24.21254258; this version posted March 26, 2021. The copyright holder for this preprint (which was not certified by peer review) is the author/funder, who has granted medRxiv a license to display the preprint in It is made available under a CC-BY-NC-ND 4.0 International license .

208 change in cognitive skills and communication. To obtain a measure of change, we subtracted 209 the scores at time-point 2 from the ones at time-point 1 (the ADOS-CSS for the level of 210 symptoms, the standard score for the cognitive skills and the age equivalents for 211 communication skills). We then used Spearman partial correlations to assess the relation 212 between imitation skills at baseline and subsequent change in symptoms of autism, cognitive 213 and communication levels a year later, while controlling for the baseline levels.

\section{Imitation trajectories within the ASD group}

215 Given the tremendous heterogeneity of the ASD phenotype (Wiggins et al., 2012), we wanted

216 to better understand the diversity of imitation profiles and their evolution in the sample of 217 children with ASD for whom we had longitudinal data (102 subjects). To this end, we used a 218 K-means clustering method, which allows grouping together subjects similar throughout 219 multiple dimensions (i.e. imitation skills at different ages) (Bair, 2013; Sandini et al., 2018). We 220 employed a two-step approach: First, to distinguish between children starting at different 221 levels of imitation skills we employed a K-means clustering on raw scores at the first time222 point. To obtain an optimal cluster number among several solutions (2-6 clusters), we used a 223 silhouette approach (Rousseeuw, 1987). Second, we applied a K-means clustering on the 224 slopes of imitation skills by age in the subgroup of children with initially lower levels of 225 imitation skills to test for divergent trajectories over time.

\section{Results}

\section{Group comparison of imitation skills}

229 Using a cross-sectional sample ( $N=220,177$ children with ASD, 43 with TD, age range: 2.0 2305.0 years old), we were able to show that the two groups differed significantly in their 231 imitations skills $(U=1270, \mathrm{p}<0.001)$. Indeed, children with ASD had markedly lower imitation 232 skills than typically developing children (see Figure 2). 
medRxiv preprint doi: https://doi.org/10.1101/2021.03.24.21254258; this version posted March 26, 2021. The copyright holder for this preprint (which was not certified by peer review) is the author/funder, who has granted medRxiv a license to display the preprint in It is made available under a CC-BY-NC-ND 4.0 International license.

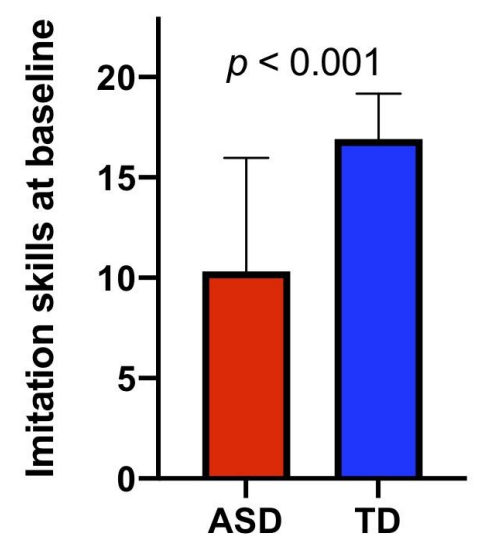

Figure 2. Group comparison of imitation skills obtained from Visuo-Motor Imitation scale of PEP-3 (raw scores).

\section{Imitation trajectories over time}

Using all available visits for our cross-sectional sample (total of 396 time-points, $N=220$, $\left.n_{A S D}=177, n_{T D}=43\right)$ we tested the between-group differences in trajectories of imitation. As shown in Figure 3, the group trajectories in imitation skills estimated using mixed-models were significantly different (group effect: $p<.001$; interaction : $p<.001$ ). The best fitted model was of the 2 nd order, meaning that the relation of the imitation with age was quadratic. Indeed, the TD children showed good imitation skills at two years old with only a slight improvement thereafter. In contrast, at the group level, children with ASD present markedly low imitation skills at a young age with substantial improvement between the ages of two and five (see Figure 3). However, we also observe that trajectories of children with ASD are very heterogeneous and this point is addressed in our later analyses.

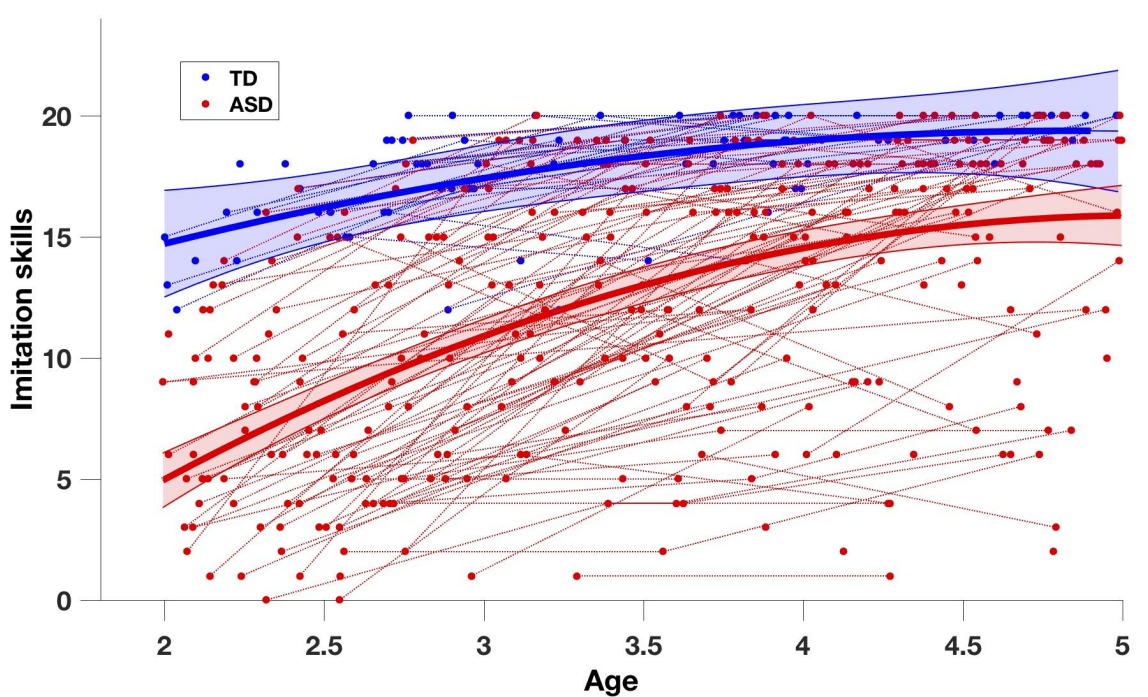

Age

250 Figure 3. Imitation trajectories over time in the ASD and TD groups. The trajectory on the group level (solid lines, red=ASD, blue=TD) is obtained using mixed-effect models (Mancini \& al., 2019; Mutlu \& al., 2013). The 95\% confidence interval of estimated group-level trajectory is represented in colored bands. Repeated time-points of the same subjects are connected with dotted lines. 
medRxiv preprint doi: https://doi.org/10.1101/2021.03.24.21254258; this version posted March 26, 2021. The copyright holder for this preprint (which was not certified by peer review) is the author/funder, who has granted medRxiv a license to display the preprint in It is made available under a CC-BY-NC-ND 4.0 International license .

\section{Results within the ASD group}

255

256

257

258

259

260

261

262

263

264

265

266

267

268

269

\section{Relation of imitation with level of symptoms and developmental domains} at baseline

Within our ASD group for whom the Mullen Scales of Early Learning was available $(n=133$, 113 males / 20 females, age range: 2.0 - 4.8 years old), imitation skills were moderately negatively related to the level of symptoms $\left(r_{s}=-0.583, p<.001\right)$, as the children who show the most of symptoms are also those with more imitation difficulties (see Figure 4). In addition, imitation skills were strongly positively correlated with the composite score of cognitive skills at baseline, as well as communication skills (Receptive and Expressive Language) (ELC $: r_{s}=$ $0.671, p<.001$, RL : $r_{s}=0.778, p<.001$, EL $: r_{s}=0.738, p<.001$ ), that is, children with lower imitation skills were also those with lower skills in these domains (see Figure 5).

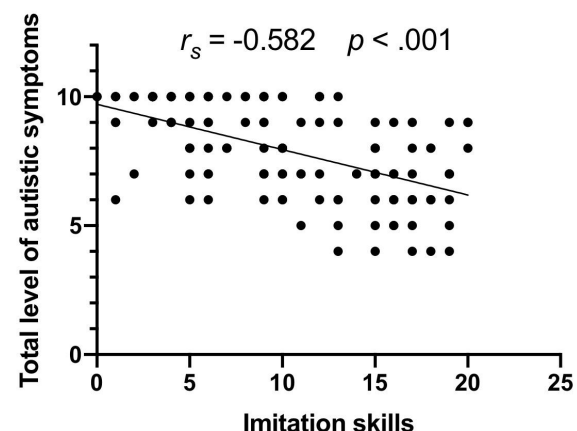

Figure 4. Spearman correlation between imitation and level of symptoms within the ASD group (VisuoMotor Imitation scale of PEP-3 and Calibrated Severity Score of ADOS-G or 2)

a)

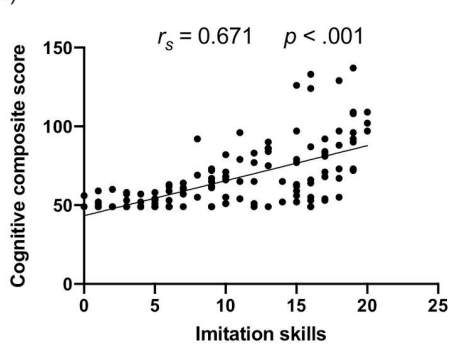

b)

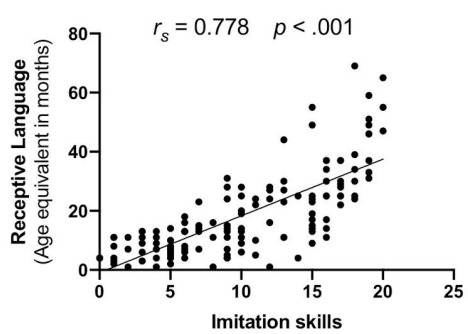

c)

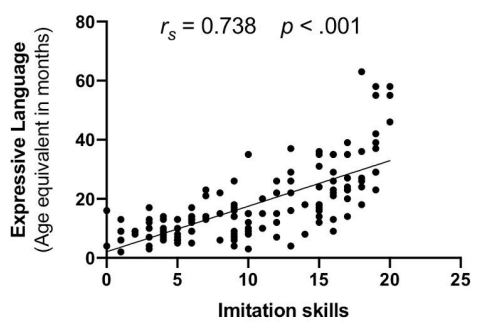

Figure 5. Spearman correlations between baseline imitation skills (raw scores of Visuo-Motor Imitation scale of PEP-3) and (a) Early Learning Composite of MSEL, (b) Receptive language age equivalent scores and (c) Expressive language age equivalent scores.

Imitation at baseline as a predictor of the autistic symptoms and developmental changes

Imitation skills at baseline were predictive of the gains in communication skills (Receptive and Expressive Language) a year later in our preschoolers with ASD (RL : $r_{s}=0.371, p=.001$, 
medRxiv preprint doi: https://doi.org/10.1101/2021.03.24.21254258; this version posted March 26, 2021. The copyright holder for this preprint (which was not certified by peer review) is the author/funder, who has granted medRxiv a license to display the preprint in It is made available under a CC-BY-NC-ND 4.0 International license .

EL : $\left.r_{s}=0.601, p<.001\right)$. Indeed, children with better imitation skills at baseline showed a greater improvement in these domains a year later (see Figure 6). This improvement was the most evident in the domain of expressive language. Further correlations between imitations skills and the composite cognitive score or the level of symptoms did not survive after correction for multiple comparisons (considering a stringent significance level at $p<.0125$ using Bonferroni correction).
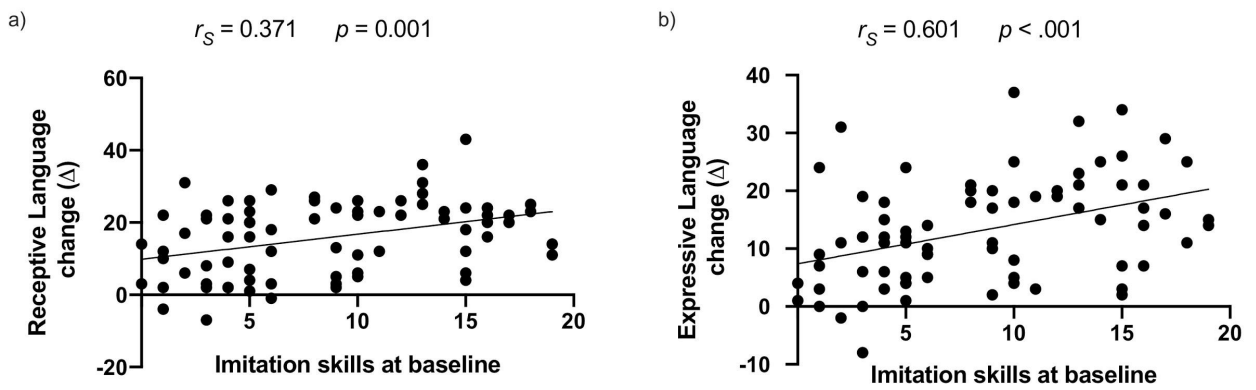

Figure 6. Spearman partial correlations between imitation skills (raw scores of the Visuo-Motor Imitation scale of PEP-3) and a one year gain in the ASD group for receptive language (a) and expressive language (b) (difference in age equivalent scores of the Mullen Scale of Early Learning).

\section{Imitation trajectories within the ASD group}

The first step of K-means clustering on the baseline raw imitation scores yielded two optimal clusters (silhouette score of 0.828). The first cluster (sub-group) of ASD children (named ASD1, $n=46$ ) (see Figure 7) had less difficulties with imitation at baseline and followed a trajectory highly similar to the one seen in our TD group (Figure 3) while the other cluster started significantly lower at baseline.

To better understand developmental trajectory in children who start lower on imitation skills, we then applied a second K-means clustering on the developmental slopes on imitation scores in our remaining group of ASD children. These children belonged to the cluster that showed less imitation skills at baseline (Total - ASD1 = 56 participants). This second clustering step yielded the two groups which we denote ASD2 and ASD3 $\left(n_{A S D 2}=27, n_{A S D 3}=29\right)$. The trajectories of the two clusters from the second clustering step were significantly different (see Figure 7), one subgroup (ASD2) had a deficit on imitation skills at two years old, but showed a great improvement until five years old while the other subgroup in ASD children (ASD3) showed many difficulties in imitation at two years old and these difficulties continue over the time (group effect : $p<.001$; interaction : $p<.001$ ).

Finally, we wanted to understand which clinical characteristics were related to the distinct imitation trajectories in our sub-samples ASD2 and ASD3. In particular, we tested the baseline differences between the two groups (ASD2 and ASD3) with regards to the level of symptoms, 
medRxiv preprint doi: $h t t p s: / / d o i . o r g / 10.1101 / 2021.03 .24 .21254258$; this version posted March 26, 2021. The copyright holder for this preprint (which was not certified by peer review) is the author/funder, who has granted medRxiv a license to display the preprint in It is made available under a CC-BY-NC-ND 4.0 International license .

cognitive and language skills, type of intervention and social orientation measured with an eye-tracking task (Franchini et al., 2017) (see Table S2 in Supplementary Materials). We found no significant baseline differences between the ASD2 and the ASD3 according to all tested clinical variables. However, by analyzing these two groups' trajectories in terms of many other aspects (communication skills, cognitive skills and adaptive behaviors), we observed that the subgroup ASD2 showed an overall improvement in all domains. This pattern suggests that imitation improvement in this group indicates an overall enhancement rather than the specific link of imitation skills progress and a particular developmental measure.

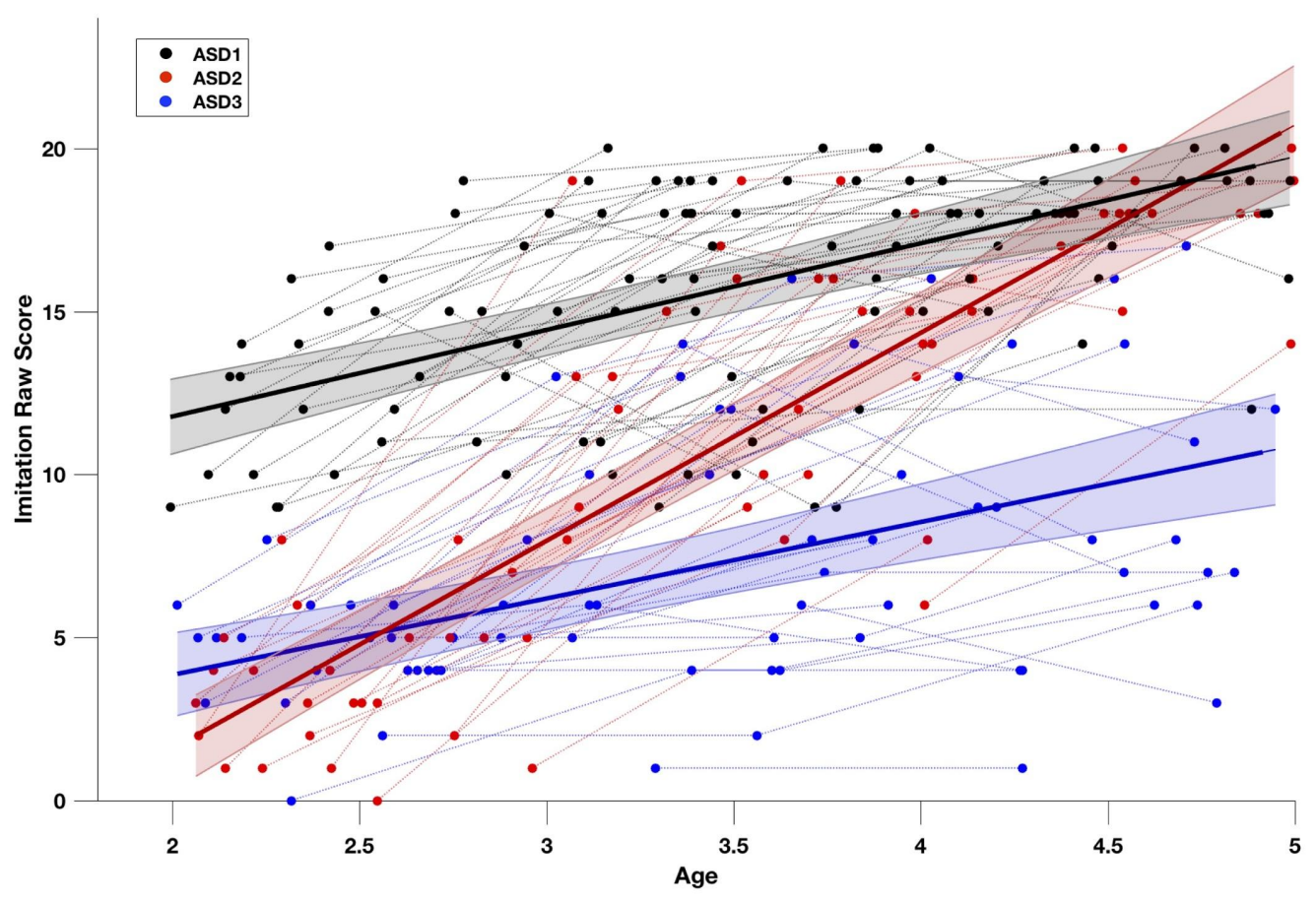

Figure 7. Imitation trajectories over time within the ASD group $(n=102)$. The trajectories at the group level (solid lines black=ASD1, $n_{A S D 1}=46$, red $=\mathrm{ASD} 2, n_{A S D 2}=27$, blue=ASD3, $n_{A S D 3}=29$ ) are obtained using mixed-effect models (Mancini \& al., 2019; Mutlu \& al., 2013). The 95\% confidence interval of estimated group-level trajectory is represented in colored bands. Repeated time-points of the same subjects are connected with dotted lines. The distribution in the sub-groups was defined by the K-means clustering method in two steps. First clustering step yielded two clusters based on imitation skills raw scores at first time-point. We retained the higher cluster (ASD1), and proceeded to the second clustering step performed on the slopes of imitation skills, yielding ASD2 and ASD3 subgroups.

\section{Discussion}

329 Our results corroborate previous findings on the imitative deficit in preschoolers with Autism 330 Spectrum Disorder (ASD) in comparison with typically developing children (TD) (Colombi \& 331 al., 2009; Girardot \& al., 2009; Ingersoll, 2008; McDuffie \& al., 2007; Plavnick \& Hume, 2014; 332 Rogers \& al., 1996; Thurm \& al., 2007; Vivanti \& Hamilton, 2014; Zwaigenbaum \& al., 2005). 
medRxiv preprint doi: https://doi.org/10.1101/2021.03.24.21254258; this version posted March 26, 2021. The copyright holder for this preprint (which was not certified by peer review) is the author/funder, who has granted medRxiv a license to display the preprint in It is made available under a CC-BY-NC-ND 4.0 International license .

Compared with our TD group, preschoolers with ASD showed significantly lower imitation skills as measured by the Visuo-Motor Imitation scale of the PEP-3 (Schopler \& al., 2005). We then explored the trajectory of imitation skills over time, which is poorly documented in the literature until now (Young \& al., 2011). Our results showed that TD children present good imitation skills, as measured with the PEP-3, already at the age of 2 years old, with only a slight improvement thereafter. In comparison, children with ASD presented a major imitative deficit at two years old, with a considerable gain up to five years old. We further confirmed that imitation skills in children with ASD at baseline were negatively related to the overall levels of symptoms while showing a positive relation with cognitive skills and language. We also showed that early imitation skills predicted the gains in communication skills one year after. Finally, we were able to delineate three different imitation trajectories in our sample of children with ASD. A subgroup of children (ASD1) presented fewer difficulties in imitation at two years old. In contrast, others (ASD2) showed major deficits in imitation at 2 years old, followed by accelerated gains up to the age of five. Lastly, we also identified a subgroup of children (ASD3) who had significant difficulties at baseline and showed less progress over the years.

\section{Developmental trajectory of imitation in ASD and TD}

Besides showing lower baseline imitative skills, we found that the acquisition of imitation skills in children with ASD did not follow the same trajectory as in TD children. In ASD children, we observed the steep progress between the age of 2 and 3.5 years, highlighting the importance of this early sensitive period for learning new skills (Dawson, 2008; Guralnick, 1997; Johnson \& Munakata, 2005; Lovaas, 1987; Vivanti et al., 2016). While most TD children reach the ceiling on this measure around the age of 5 years, the ASD group showed a lower average skill level at this age. Previous studies have suggested that the imitation deficits in ASD are more specific than broad (Rogers \& Williams, 2006), concerning for example, more meaningless gestures than actions on the objects. Nevertheless, our results speak in favor of a more broad impairment as most of the actions measured by the imitation scale we used are rather simple one-step actions on objects and relatively few concern more abstract meaningless gestures. These difficulties in imitation of simple actions with objects can have deleterious effects on learning (Ingersoll, 2008; Ingersoll \& Meyer, 2011; Poon et al., 2012; Villalobos et al., 2005). Indeed, our results showed that imitation skills were related to composite cognitive skills and communication skills (receptive and expressive language) in toddlers with ASD. As proposed by several authors (e.g. Wadsworth \& al., 2017) a child with major imitative difficulties shows delay in the acquisition of new skills, especially because he/she does not use this channel to learn from her/his parents, siblings and peers (e.g. Howe \& al., 2018; Zmyj \& Seehagen, 2013).

In addition, confirming previous studies (McDuffie et al., 2007; Rogers et al., 2003; Zachor et al., 2010), our results showed a strong correlation between imitation skills and the level of 
medRxiv preprint doi: https://doi.org/10.1101/2021.03.24.21254258; this version posted March 26, 2021. The copyright holder for this preprint (which was not certified by peer review) is the author/funder, who has granted medRxiv a license to display the preprint in It is made available under a CC-BY-NC-ND 4.0 International license .

372

symptoms measured by the ADOS-2 (Lord \& al., 2012), whereby the children with more difficulties in imitation had also more symptoms of ASD at baseline. Thus, imitation skills were clinically informative of the severity of the level of autistic symptoms. This result corroborates findings claiming the importance of imitation in the acquisition of early tools of communication and its contribution to autistic symptoms (Hanika \& Boyer, 2019; Ingersoll, 2008; Toth et al., 2006; Villalobos et al., 2005). Indeed, difficulties of engagement in reciprocal imitation early on may greatly limit social learning opportunities, lower the experiences of sharing and joint attention, important for socio-communicative development (Franchini et al., 2017). Moreover, taking part in imitation activities prepares the first basis of communication turns. Thus from the earliest moments, the reciprocal imitation of vocalisations and facial expressions in face-to-face interactions paves the way for the development of a more complex social interchange (Trevarthen et al., 1999, as cited by Ingersoll, 2008).

\section{Imitation as a predictor of developmental domains in children} with ASD

While previous studies demonstrated that imitation predicts future cognitive skills (Hurley \& Chater, 2005; Rogers \& Pennington, 1991; Strid et al., 2006; Vivanti et al., 2013), the correlation that we observed in our sample did not hold after Bonferroni correction. The same was true for the relationship between imitation and change in the severity of autistics symptoms. Nevertheless, the baseline imitation skills were predictive of communication development one year later. Especially, gains in expressive language were greater in children with better imitation skills at baseline. The link between imitation and language has already been explored in previous studies (Heimann \& al., 2016; Stone \& al., 1997; Stone \& Yoder, 2001; Toth \& al., 2006). Indeed, infants start by imitating vocalizations, exchanges of vocalizations, then later words and sentences (e.g. Jones, 2007). Some studies found that verbal imitation (Smith et al., 2007) but also body movements imitation (Stone et al., 1997) are predictors of expressive language development.

Although children with ASD at a group level showed important gains in imitation skills, between two and five years old, the early difficulties in this domain presented at the age of two could still have an important influence on learning later on. Imitation is important not only for children's current achievements, but also for their future skills. Learning to imitate can then be considered as one of the primary goals in early intervention programs for children with ASD (Rogers \& Dawson, 2010), which can then be used to build on this skill for future acquisitions. 
medRxiv preprint doi: https://doi.org/10.1101/2021.03.24.21254258; this version posted March 26, 2021. The copyright holder for this preprint (which was not certified by peer review) is the author/funder, who has granted medRxiv a license to display the preprint in It is made available under a CC-BY-NC-ND 4.0 International license .

\section{Imitation trajectories within the ASD group}

408 Given the important heterogeneity of the ASD phenotype (Wiggins et al., 2012), we explored 409 the extent to which there might be different developmental trajectories of imitation within our 410 sample of children with ASD. Although some authors have studied the trajectories of different 411 types of imitation in children with ASD (Sanefuji \& Yamamoto, 2014), to the best of our 412 knowledge, no study to date tried to parse the heterogeneity of the early imitation 413 development in ASD. Here, using a clustering approach, we observed three separate imitation 414 trajectories in children with ASD. Similar to previous studies (Charman et al., 2003; Stone et 415 al., 1997; Stone \& Yoder, 2001; Vivanti et al., 2013), we found that good early imitation skills 416 are linked to better outcomes, while early difficulties predict impairment in developmental 417 domains. Nevertheless, our study showed that some children with ASD have major 418 difficulties in imitation at 2 years old, but show a great improvement until 5 years of age. As mentioned previously, we were not able to find a characteristic that would differentiate these two groups at baseline and predict whether a child with imitation difficulties at baseline will follow one trajectory or the other. However, our results support that imitation improvement is an indicator of an overall enhancement, without a clear causal relationship with the used measures. More investigation should be done to understand the mechanisms through which a child's development is set on one trajectory or the other. The absence of evidence for specific differences between the two groups with a divergent imitation trajectory is interpreted with caution. Indeed, imitation is often used to incite and encourage the child to do the exercises in assessments such as the one used in this study (MSEL; Mullen, 1995), specifically when there are difficulties of language comprehension, as it is frequently the case in young children with ASD (Kwok et al., 2015). Thus, a low score on domains of cognitive or language skills could, in some cases, be better explained by maladaptive behaviors than by real difficulties in these areas (Robain et al., 2020).

\section{Perspectives and limitations}

433 As a limitation to this study, we would like to emphasize that the imitation skills measured in the context of our study are elementary skills, and concern mainly actions with objects. Thus, it would be particularly interesting to refine the analyses using a scale adapted for a larger age range, with a broader variety of activities, allowing differentiation of different imitation types as described by Vivanti \& Hamilton (2014).

There are many avenues to pursue to better understand the mechanisms underlying imitation in young children with ASD. Indeed, as discussed, it would be particularly interesting and valuable to find an early predictor of the developmental trajectory in children with early imitation difficulties. We showed that the children with an imitation deficit at 2 years will 
medRxiv preprint doi: https://doi.org/10.1101/2021.03.24.21254258; this version posted March 26, 2021. The copyright holder for this preprint (which was not certified by peer review) is the author/funder, who has granted medRxiv a license to display the preprint in It is made available under a CC-BY-NC-ND 4.0 International license .

444

445

446

447

448

449

450

451

452

453

454

455

456

457

458

459

460

461

462

463

464

465

466

467

468

469 Funding

470 This research was funded by the National Center of Competence in Research "Synapsy" of

improvement in imitation but also in other areas in general. It would then be a question of finding which characteristics of the behavioral phenotype, or the interventions received allowed the positive evolution in some cases. One of the avenues to follow in this sense could be to explore earlier milestones of imitation than one measured in our study. Indeed, imitation is very linked to other skills such as social orientation, joint attention and social reciprocity as demonstrated by some authors (Girardot et al., 2009; McDuffie et al., 2007). Despite our unsuccessful attempt to distinguish our two groups in terms of social orientation using an eye-tacking task (Franchini et al., 2017), more investigations could be done in this sense with a younger sample.

\section{Conclusions}

Our study confirmed a delay in the acquisition of imitation skills in preschoolers with ASD who present a different developmental trajectory than children with typical development. We also showed that these difficulties are related to levels of autistic symptoms, developmental deficits, and long-term consequences on the development of communication and composite cognitive skills. Moreover, our analyses identified subgroups of children with ASD in terms of imitative development, reflecting the heterogeneity that characterizes this population. Thus, our study confirms the status of imitation as a prerequisite for the development of other skill areas and the importance of including its learning in early intervention programs, for example.

\section{Acknowledgements}

The authors are particularly grateful to all the families who participated in this study. Furthermore, the authors thank Lylia Ben Hadid, François Robain, Sonia Richetin, Sara Maglio, Aurélie Bochet, Michel Godel, Stefania Solazzo, Ornella Vico Begara, Chiara Usuelli, Eva Micol, Laura Sallin, Lisa Esposito, Kenza Latrèche, Oriane Grosvernier and Constance Ferrat for their implication in data collection. the Swiss National Science Foundation (SNF, grant number: 51AU40_125759), and by a SNF grant to M.S. (\#163859). This work was also partially supported by the Foundation of the Geneva University Hospital (http://www.fondationhug.org) and by the "Fondation Pôle Autisme" (http://www.pole-autisme.ch). 
medRxiv preprint doi: https://doi.org/10.1101/2021.03.24.21254258; this version posted March 26, 2021. The copyright holder for this preprint (which was not certified by peer review) is the author/funder, who has granted medRxiv a license to display the preprint in It is made available under a CC-BY-NC-ND 4.0 International license.

\section{Conflicts of Interest}

476 The authors declare no conflict of interest. The funders had no role in the design of the study;

477 in the collection, analysis, or interpretation of data; in the writing of the manuscript, or in the

478 decision to publish the results.

479 Bibliography

480

481 American Psychiatric Association. (2013). Diagnostic and statistical manual of mental disorders (DSM-5®). American Psychiatric Pub.

Bair, E. (2013). Semi-supervised clustering methods. WIREs Computational Statistics, 5(5), 349-361. https://doi.org/10.1002/wics.1270

Charman, T., Baron-Cohen, S., Swettenham, J., Baird, G., Drew, A., \& Cox, A. (2003). disorder. International Journal of Language \& Communication Disorders, 38(3), 265-285. https://doi.org/10.1080/136820310000104830

Colombi, C., Liebal, K., Tomasello, M., Young, G., Warneken, F., \& Rogers, S. J. (2009). understanding intentions. Autism, 13(2), 143-163.

Dawson, G. (2008). Early behavioral intervention, brain plasticity, and the prevention of autism spectrum disorder. Development and Psychopathology, 20(3), 775-803. https://doi.org/10.1017/S0954579408000370 
medRxiv preprint doi: https://doi.org/10.1101/2021.03.24.21254258; this version posted March 26, 2021. The copyright holder for this preprint (which was not certified by peer review) is the author/funder, who has granted medRxiv a license to display the preprint in It is made available under a CC-BY-NC-ND 4.0 International license

Delano, M. E. (2007). Video Modeling Interventions for Individuals with Autism. Remedial and Special Education, 28(1), 33-42. https://doi.org/10.1177/07419325070280010401

Espanola Aguirre, E., \& Gutierrez, A. (2019). An Assessment and Instructional Guide for Motor and Vocal Imitation. Journal of Autism and Developmental Disorders, 49(6), 25452558. https://doi.org/10.1007/s10803-019-04008-x

Franchini, M., Glaser, B., Wilde, H. W. de, Gentaz, E., Eliez, S., \& Schaer, M. (2017). Social orienting and joint attention in preschoolers with autism spectrum disorders. PLOS

Franchini, M., Wood de Wilde, H., Glaser, B., Gentaz, E., Eliez, S., \& Schaer, M. (2016). Brief Report: A Preference for Biological Motion Predicts a Reduction in Symptom Severity 1 Year Later in Preschoolers with Autism Spectrum Disorders. Frontiers in Schaer, M. (2018). Early Adaptive Functioning Trajectories in Preschoolers With Autism Spectrum Disorders. Journal of Pediatric Psychology, 43(7), 800-813. Hill, NC: University of North Carolina at Chapel Hill.

518 Girardot, A. M., De Martino, S., Rey, V., \& Poinso, F. (2009). Étude des relations entre l'imitation, l'interaction sociale et l'attention conjointe chez les enfants autistes. Neuropsychiatrie de l'Enfance et de l'Adolescence, 57(4), 267-274. https://doi.org/10.1016/j.neurenf.2008.09.009

522 Gotham, K., Pickles, A., \& Lord, C. (2009). Standardizing ADOS Scores for a Measure of 
medRxiv preprint doi: https://doi.org/10.1101/2021.03.24.21254258; this version posted March 26, 2021. The copyright holder for this preprint (which was not certified by peer review) is the author/funder, who has granted medRxiv a license to display the preprint in It is made available under a CC-BY-NC-ND 4.0 International license

Severity in Autism Spectrum Disorders. Journal of Autism and Developmental Disorders, 39(5), 693-705. https://doi.org/10.1007/s10803-008-0674-3

Guralnick, M. J. (1997). Effectiveness of Early Intervention for Vulnerable Children: A Developmental Perspective. American Journal on Mental Retardation, 102(4), 319-345. https://doi.org/10.1352/0895-8017(1998)102<0319:EOEIFV>2.0.CO;2

Hanika, L., \& Boyer, W. (2019). Imitation and Social Communication in Infants. Early Childhood Education Journal, 47(5), 615-626. https://doi.org/10.1007/s10643-019-00943-7

Heimann, M., Nordqvist, E., Strid, K., Almrot, J. C., \& Tjus, T. (2016). Children with autism respond differently to spontaneous, elicited and deferred imitation. Journal of Intellectual Disability Research, 60(5), 491-501. https://doi.org/10.1111/jir.12272

Heimann, M., \& Tjus, T. (2019). Neonatal imitation: Temporal characteristics in imitative response patterns. Infancy, 24(5), 674-692. https://doi.org/10.1111/infa.12304 assistant ogre": The Social Function of Sibling Imitation in Early Childhood. Infant

Hurley, S. L., \& Chater, N. (2005). Perspectives on Imitation: Imitation, human development, and culture. MIT Press.

Ingersoll, B. (2008). The Social Role of Imitation in Autism: Implications for the Treatment of Imitation Deficits. Infants \& Young Children, 21(2), 107. https://doi.org/10.1097/01.IYC.0000314482.24087.14 young children with autism spectrum disorders. Research in Autism Spectrum Disorders, 5(3), 1078-1085. https://doi.org/10.1016/j.rasd.2010.12.001

Johnson, M. H., \& Munakata, Y. (2005). Processes of change in brain and cognitive 
medRxiv preprint doi: https://doi.org/10.1101/2021.03.24.21254258; this version posted March 26, 2021. The copyright holder for this preprint (which was not certified by peer review) is the author/funder, who has granted medRxiv a license to display the preprint in It is made available under a CC-BY-NC-ND 4.0 International license development. Trends in Cognitive Sciences, 9(3), 152-158. https://doi.org/10.1016/j.tics.2005.01.009

Jones, S. S. (2007). Imitation in Infancy: The Development of Mimicry. Psychological Science, 18(7), 593-599. https://doi.org/10.1111/j.1467-9280.2007.01945.x

Kojovic, N., Ben Hadid, L., Franchini, M., \& Schaer, M. (2019). Sensory Processing Issues and Their Association with Social Difficulties in Children with Autism Spectrum Disorders. Journal of Clinical Medicine, 8(10), 1508. https://doi.org/10.3390/jcm8101508

Kwok, E. Y. L., Brown, H. M., Smyth, R. E., \& Oram Cardy, J. (2015). Meta-analysis of receptive and expressive language skills in autism spectrum disorder. Research in Autism Spectrum Disorders, 9, 202-222. https://doi.org/10.1016/j.rasd.2014.10.008 diagnostic observation schedule-2nd edition (ADOS-2). Los Angeles, CA: Western Psychological Corporation.

Lord, Catherine, Risi, S., Lambrecht, L., Cook, E. H., Leventhal, B. L., DiLavore, P. C., Pickles, A., \& Rutter, M. (2000). The Autism Diagnostic Observation ScheduleGeneric: A Standard Measure of Social and Communication Deficits Associated with the Spectrum of Autism. Journal of Autism and Developmental Disorders, 30(3), 205-223.

Lovaas, O. I. (1987). Behavioral treatment and normal educational and intellectual functioning in young autistic children. Journal of Consulting and Clinical Psychology, 55(1), 3-9. https://doi.org/10.1037/0022-006X.55.1.3 
medRxiv preprint doi: https://doi.org/10.1101/2021.03.24.21254258; this version posted March 26, 2021. The copyright holder for this preprint (which was not certified by peer review) is the author/funder, who has granted medRxiv a license to display the preprint in It is made available under a CC-BY-NC-ND 4.0 International license https://doi.org/10.1186/s11689-016-9141-1

572

573

574

575

576

577

578

579

580

581

582

583

584

585

Mancini, V., Sandini, C., Padula, M. C., Zöller, D., Schneider, M., Schaer, M., \& Eliez, S. (2019). Positive psychotic symptoms are associated with divergent developmental trajectories of hippocampal volume during late adolescence in patients with 22q11DS. Molecular Psychiatry, 1-16. https://doi.org/10.1038/s41380-019-0443-z

McDuffie, A., Turner, L., Stone, W., Yoder, P., Wolery, M., \& Ulman, T. (2007). Developmental Correlates of Different Types of Motor Imitation in Young Children with Autism Spectrum Disorders. Journal of Autism and Developmental Disorders, 37(3), 401-412. https://doi.org/10.1007/s10803-006-0175-1

Meltzoff, A. N., \& Moore, M. K. (1989). Imitation in newborn infants: Exploring the range of gestures imitated and the underlying mechanisms. Developmental Psychology, 25(6), 954. https://doi.org/10.1037/0012-1649.25.6.954

Mullen, E. (1995). Mullen Scales of Early Learning (MSEL) manual. Circle Pines, NY: American.

Mutlu, A. K., Schneider, M., Debbané, M., Badoud, D., Eliez, S., \& Schaer, M. (2013). Sex differences in thickness, and folding developments throughout the cortex. NeuroImage, 82, 200-207. https://doi.org/10.1016/j.neuroimage.2013.05.076

Pfeifer, J. H., Iacoboni, M., Mazziotta, J. C., \& Dapretto, M. (2008). Mirroring others' emotions relates to empathy and interpersonal competence in children. Neurolmage, 39(4), 2076-2085. https://doi.org/10.1016/j.neuroimage.2007.10.032

Plavnick, J. B., \& Hume, K. A. (2014). Observational learning by individuals with autism: A review of teaching strategies. Autism, 18(4), 458-466. https://doi.org/10.1177/1362361312474373

Poon, K. K., Watson, L. R., Baranek, G. T., \& Poe, M. D. (2012). To What Extent Do Joint 
medRxiv preprint doi: https://doi.org/10.1101/2021.03.24.21254258; this version posted March 26, 2021. The copyright holder for this preprint (which was not certified by peer review) is the author/funder, who has granted medRxiv a license to display the preprint in It is made available under a CC-BY-NC-ND 4.0 International license

595

596

597

598

599

600

601

602

603

604

605

606

607

608

609

610

611

612

613

614

615

616

617

618

Attention, Imitation, and Object Play Behaviors in Infancy Predict Later

Communication and Intellectual Functioning in ASD? Journal of Autism and Developmental Disorders, 42(6), 1064-1074. https://doi.org/10.1007/s10803-011-1349-z

Robain, F., Franchini, M., Kojovic, N., Wood de Wilde, H., \& Schaer, M. (2020). Predictors of Treatment Outcome in Preschoolers with Autism Spectrum Disorder: An Observational Study in the Greater Geneva Area, Switzerland. Journal of Autism and Developmental Disorders. https://doi.org/10.1007/s10803-020-04430-6

Rogers, S. J., Bennetto, L., McEvoy, R., \& Pennington, B. F. (1996). Imitation and Pantomime in High-Functioning Adolescents with Autism Spectrum Disorders. Child Development, 67(5), 2060-2073. https://doi.org/10.1111/j.1467-8624.1996.tb01843.x

Rogers, S. J., \& Dawson, G. (2010). Early Start Denver Model for young children with autism. New York, NY: Guilford.

Rogers, S. J., Hepburn, S. L., Stackhouse, T., \& Wehner, E. (2003). Imitation performance in toddlers with autism and those with other developmental disorders. Journal of Child Psychology and Psychiatry, 44(5), 763-781. https://doi.org/10.1111/1469-7610.00162

Rogers, S. J., \& Pennington, B. F. (1991). A theoretical approach to the deficits in infantile autism. Development and Psychopathology, 3(2), 137-162. https://doi.org/10.1017/S0954579400000043

Rogers, S. J., \& Williams, J. H. G. (2006). Imitation and the Social Mind: Autism and Typical Development. Guilford Press.

Rousseeuw, P. J. (1987). Silhouettes: A graphical aid to the interpretation and validation of cluster analysis. Journal of Computational and Applied Mathematics, 20, 53-65. https://doi.org/10.1016/0377-0427(87)90125-7

Rowberry, J., Macari, S., Chen, G., Campbell, D., Leventhal, J. M., Weitzman, C., \& 
medRxiv preprint doi: https://doi.org/10.1101/2021.03.24.21254258; this version posted March 26, 2021. The copyright holder for this preprint (which was not certified by peer review) is the author/funder, who has granted medRxiv a license to display the preprint in It is made available under a CC-BY-NC-ND 4.0 International license Chawarska, K. (2015). Screening for Autism Spectrum Disorders in 12-Month-Old High-Risk Siblings by Parental Report. Journal of Autism and Developmental Disorders, 45(1), 221-229. https://doi.org/10.1007/s10803-014-2211-x

622

Sandini, C., Zöller, D., Scariati, E., Padula, M. C., Schneider, M., Schaer, M., Van De Ville, D., \& Eliez, S. (2018). Development of Structural Covariance From Childhood to Adolescence: A Longitudinal Study in 22q11.2DS. Frontiers in Neuroscience, 12. https://doi.org/10.3389/fnins.2018.00327

Sanefuji, W., \& Yamamoto, T. (2014). The Developmental Trajectory of Imitation in Infants with Autism Spectrum Disorders: A Prospective Study. Psychology, 05(11), 1313. https://doi.org/10.4236/psych.2014.511142

Schneider, M., Schaer, M., Mutlu, A. K., Menghetti, S., Glaser, B., Debbané, M., \& Eliez, S. (2014). Clinical and cognitive risk factors for psychotic symptoms in 22q11.2 deletion syndrome: A transversal and longitudinal approach. European Child \& Adolescent Psychiatry, 23(6), 425-436. https://doi.org/10.1007/s00787-013-0469-8

Schopler, E., Lansing, M. D., Reichler, R. J., \& Marcus, L. M. (2005). PEP-3, Psychoeducational Profile. Pro-Ed.

Smith Veronica, Mirenda Pat, \& Zaidman-Zait Anat. (2007). Predictors of Expressive Vocabulary Growth in Children With Autism. Journal of Speech, Language, and Hearing Research, 50(1), 149-160. https://doi.org/10.1044/1092-4388(2007/013)

Sperdin, H. F., Coito, A., Kojovic, N., Rihs, T. A., Jan, R. K., Franchini, M., Plomp, G., Vulliemoz, S., Eliez, S., Michel, C. M., \& Schaer, M. (2018). Early alterations of social brain networks in young children with autism. ELife, 7, e31670. https://doi.org/10.7554/eLife.31670

Stone, W. L., Ousley, O. Y., \& Littleford, C. D. (1997). Motor Imitation in Young Children 
medRxiv preprint doi: https://doi.org/10.1101/2021.03.24.21254258; this version posted March 26, 2021. The copyright holder for this preprint (which was not certified by peer review) is the author/funder, who has granted medRxiv a license to display the preprint in It is made available under a CC-BY-NC-ND 4.0 International license

643

644

645

646

647

648

649

650

651

652

653

654

655

656

657

658

659

660

661

662

663

664

665

666

with Autism: What's the Object? Journal of Abnormal Child Psychology, 25(6), 475-485. https://doi.org/10.1023/A:1022685731726

Stone, W. L., \& Yoder, P. J. (2001). Predicting Spoken Language Level in Children with Autism Spectrum Disorders. Autism, 5(4), 341-361. https://doi.org/10.1177/1362361301005004002

Strid, K., Tjus, T., Smith, L., Meltzoff, A. N., \& Heimann, M. (2006). Infant recall memory and communication predicts later cognitive development. Infant Behavior and Development, 29(4), 545-553. https://doi.org/10.1016/j.infbeh.2006.07.002

Thurm, A., Lord, C., Lee, L.-C., \& Newschaffer, C. (2007). Predictors of Language Acquisition in Preschool Children with Autism Spectrum Disorders. Journal of Autism and Developmental Disorders, 37(9), 1721-1734. https://doi.org/10.1007/s10803-0060300-1

Toth, K., Munson, J., N. Meltzoff, A., \& Dawson, G. (2006). Early Predictors of Communication Development in Young Children with Autism Spectrum Disorder: Joint Attention, Imitation, and Toy Play. Journal of Autism and Developmental Disorders, 36(8), 993-1005. https://doi.org/10.1007/s10803-006-0137-7

Trevarthen, C., Kokkinaki, T., \& Fiamenghi Jr., G. A. (1999). What infants' imitations communicate: With mothers, with fathers and with peers. In Imitation in infancy (pp. 127-185). Cambridge University Press.

Uzgiris, I. C. (1981). Two Functions of Imitation During Infancy. International Journal of Behavioral Development, 4(1), 1-12. https://doi.org/10.1177/016502548100400101

Villalobos, M. E., Mizuno, A., Dahl, B. C., Kemmotsu, N., \& Müller, R.-A. (2005). Reduced functional connectivity between V1 and inferior frontal cortex associated with visuomotor performance in autism. Neurolmage, 25(3), 916-925. 
medRxiv preprint doi: https://doi.org/10.1101/2021.03.24.21254258; this version posted March 26, 2021. The copyright holder for this preprint (which was not certified by peer review) is the author/funder, who has granted medRxiv a license to display the preprint in It is made available under a CC-BY-NC-ND 4.0 International license

667

668

669

670

671

672

673

674

675

676

677

678

679

680

681

682

683

684

685

686

687

688

689

690

https://doi.org/10.1016/j.neuroimage.2004.12.022

Vivanti, G., Dissanayake, C., \& The Victorian ASELCC Team. (2016). Outcome for Children Receiving the Early Start Denver Model Before and After 48 Months. Journal of Autism and Developmental Disorders, 46(7), 2441-2449. https://doi.org/10.1007/s10803016-2777-6

Vivanti, G., Dissanayake, C., Zierhut, C., Rogers, S. J., \& Victorian ASELCC Team. (2013). Brief report: Predictors of outcomes in the Early Start Denver Model delivered in a group setting. Journal of Autism and Developmental Disorders, 43(7), 1717-1724. https://doi.org/10.1007/s10803-012-1705-7

Vivanti, G., \& Hamilton, A. (2014). Imitation in Autism Spectrum Disorders. In Handbook of Autism and Pervasive Developmental Disorders, Fourth Edition. American Cancer Society. https://doi.org/10.1002/9781118911389.hautc12

Wadsworth, H. M., Maximo, J. O., Lemelman, A. R., Clayton, K., Sivaraman, S., Deshpande, H. D., Ver Hoef, L., \& Kana, R. K. (2017). The Action Imitation network and motor imitation in children and adolescents with autism. Neuroscience, 343, 147-156. https://doi.org/10.1016/j.neuroscience.2016.12.001

Wiggins, L. D., Robins, D. L., Adamson, L. B., Bakeman, R., \& Henrich, C. C. (2012). Support for a Dimensional View of Autism Spectrum Disorders in Toddlers. Journal of Autism and Developmental Disorders, 42(2), 191-200. https://doi.org/10.1007/s10803-011-1230-0

Young, G. S., Rogers, S. J., Hutman, T., Rozga, A., Sigman, M., \& Ozonoff, S. (2011). Imitation from 12 to 24 months in autism and typical development: A longitudinal Rasch analysis. Developmental Psychology, 47(6), 1565. https://doi.org/10.1037/a0025418

Zachor, D. A., Ilanit, T., \& Itzchak, E. B. (2010). Autism severity and motor abilities correlates of imitation situations in children with autism spectrum disorders. Research in Autism 
medRxiv preprint doi: https://doi.org/10.1101/2021.03.24.21254258; this version posted March 26, 2021. The copyright holder for this preprint (which was not certified by peer review) is the author/funder, who has granted medRxiv a license to display the preprint in It is made available under a CC-BY-NC-ND 4.0 International license.

691 Spectrum Disorders, 4(3), 438-443. https://doi.org/10.1016/j.rasd.2009.10.016

692 Zmyj, N., \& Seehagen, S. (2013). The Role of a Model's Age for Young Children's Imitation:

693

694

695

696

697

698

699
A Research Review. Infant and Child Development, 22(6), 622-641.

https://doi.org/10.1002/icd.1811

Zwaigenbaum, L., Bryson, S., Rogers, T., Roberts, W., Brian, J., \& Szatmari, P. (2005).

Behavioral manifestations of autism in the first year of life. International Journal of Developmental Neuroscience, 23(2), 143-152.

https://doi.org/10.1016/j.ijdevneu.2004.05.001 